\title{
Corruption Perception and Sustainable Development: Sharing Botswana's Anti-Graft Agency Experiences
}

\author{
Gbolahan Gbadamosi \\ Worcester Business School, University of Worcester
}

\begin{abstract}
Unethical practices and corruption issues have become one of the greatest challenges to Africans and their leaders, threatening to undermine economic growth, democratic stability and sustenance, and general developmental efforts. Against this background, this paper examines corruption perception in Africa using indicators of Transparency International as benchmark. The costs of corruption to the continent's progress were highlighted. The paper also focuses on Botswana's efforts to fight corruption through its Directorate on Corruption and Economic Crime (DCEC). The factors that have aided the qualified successes of the anti-corruption efforts as well as lessons that may be learnt by other African countries are discussed.
\end{abstract}

JEL 017, Q01

\section{1}

\section{Introduction}

Creating a system of governance that advances, supports and sustains human development, assuring all stakeholders of the openness and transparency of the system is a challenge all societies must face up to. The perceived absence of integrity in any system weakens the credibility of that system. While issues of good governance and transparency remain vital in any setting, it is particularly important in poorer countries in their desire to break the vicious cycle of poverty and underdevelopment. Because corruption restricts investments and economic growth and undermines programmes aimed at poverty alleviation, it is critical to any discourse on a developing nation, and particularly critical for Africa. Nevertheless, all societies - irrespective of the level of development - need to create a state devoid of mismanagement, as corruption is indicative of this state of affairs.

Any discussion around ethical considerations can be very controversial. The reason is not farfetched; being good, bad, right, wrong fair, or unfair is very relative. It could be contingent on the situation, the issues involved or the individual giving the judgement. In our daily transactions we feel an obligation to consider not only our personal well-being, but also that of other persons. Ethics is, therefore, a code of behaviour that a society considers moral and appropriate for guiding our relationships with one another. The issues at stake here include honesty and integrity, as well as fair, open and straightforward dealing. It involves conforming to the golden rule "do unto others as you would have them do unto you".

In its simplest form corruption refers to the abuse of power, most often for personal gain or for the benefit of a group to which one owes allegiance (Stapenhurst \& Shahrzad, 1999). Corruption can be motivated by greed or the desire to retain or increase one's power, and is found in virtually every sphere of life. While many regard corruption as a problem of significantly poor and developing countries, Girling (1997) argues that corruption does not disappear as countries develop and modernise, instead it takes new forms. Corruption is symptomatic of a deeper problem: the collusive system in which politicians mediate the often contradictory claims of capitalism and 
democracy; it stems from incompatibility in important aspects of the economic and political systems, thus it is more than a "criminal problem", it is a social problem: the product of economic, political, and cultural forces (Girling, 1997). Indeed, this is the way in which many societies perceive and act on corruption.

While there is a tendency for people to generally view unethical conduct as relating only to issues of financial exchange between persons to induce favours, that is, being corrupt, it is indeed an over-simplistic argument and a poor understanding of the details of unethical conduct. Issues of unethical conduct include the issues of exchange of gifts, requests for loans, conflict of interest, misuse of position by abusing one's office, including misusing confidential information, government property and official time, among others. Corruption is part of the moral degeneration that is sweeping across the entire world. Ideally organisations, nay societies, should have Codes of Conduct for their people, especially those in positions of power and responsibility, so that they can commit themselves to principles of incorruptibility, integrity, openness and respect. This calls on people to live honestly and positively and to promote fairness and impartiality.

The choice of Botswana as the African country of focus in this paper is guided by the general positive popular press report of Botswana being the "African success story" over the last few years (for example, BBC, March 2005). To what extent is this really true? From being one of the poorest countries in the world at independence, Botswana is now classified by the World Bank as an upper middle income country, with a per capita GDP at purchasing power parity of almost $\$ 8000$ (Human Development Report, 2003:280 and Republic of Botswana, 2001). This paper attempts a description and general evaluation of government efforts at combating corruption in the country, while provoking the prospect of other developing countries, especially those with similar features and characteristics, to possibly learn a thing or two from the relative and qualified success of Botswana's anti-graft agency experiences.

\section{The cost of corruption in Africa}

The cost and effect of corruption in Africa is very high. It includes costs to the nation, organisations and indeed individuals. It is difficult to quantify the cost of corruption to a country because it comes in many forms, monetary as well as human. The World Bank (1997) noted that corruption has the effect of distorting public expenditures, increasing the costs of running a business and diverting resources from the poor to the rich. Corruption deters investment because it is a disincentive to prospective investors, thereby inhibiting economic growth. It undermines programmes designed specifically to aid the poor, the poor are harmed by systemic corruption (UNDP Discussion Paper, 1997). Stapenhurst \& Sedigh (1999) enumerated the cost of corruption as distorting choice; damaging the economic life of society; increasing cost of goods and services; promoting unproductive investment in projects that are not economically viable or sustainable; contributing to a decline in standards; and possibly increasing a country's indebtedness and impoverishment. It is arguable that even consumers are not left out, as they might pay higher prices for goods and services because the cost of corruption has been built in.

Being the largest spenders in most African countries, the public sector, especially government departments, are the pinpoint of most corrupt practices. The press is awash with several cases of inflated contracts, unsupervised government projects, unrestricted importation of locally available materials, collusion in tax evasion, among other experiences leading to stunted development as a result of significant public funds diverted for personal uses. Oliver de Sardan (1999) perhaps best captures the view noting that everyone who lives in Africa and many of those who have visited, have routine experience in dealing with corruption, since it is part of the social landscape.

The values and norms of the people are also distorted as a result of corruption, thus undermining moral standards and promoting charlatans to the detriment of honest endeavours. 
Where bribes are paid, for example to law enforcement officers, confidence in the criminal justice system is reduced and people may begin to take laws into their hands to get their own kind of justice, thereby undermining the rule of law. If those involved in corrupt practices are not caught and investigated, the cost of the corruption can never really be known.

\section{3}

\section{Corruption perception in Africa}

High ethical standards and low corruption perception will always be relevant and acclaimed in organisations and human societies. Religious, philosophical and psychological inputs all play some part in the manifestations of unethical behaviour. Businesses therefore need to be concerned with the overall moral environment. Such concerns will possibly expose ways in which good people may unwittingly take part in morally questionable activities. Gibson (2000) identified four types of excuses generally made in unethical conduct: "I was told to do it; Everybody's doing it; My actions won't make any difference; and It's not my problem". While corruption may be difficult to describe, it is certainly not difficult to recognise when encountered up close and personal or even observed from afar (Hope, 2002).

Generally, in organisations and most business settings, personal weakness, temptation, societal pressure and poor operating systems (where checks and balances are absent or weak) are perhaps the most prevalent grounds of unethical behaviour. The interesting part is that the individual knows very well what is the right action to take, but does not have the fortitude to take the right action. Everyone, or nearly so, knows and can recognise a "bribe" when faced with one, but may redefine it as "gratitude" for a service rendered and often the common justification in most settings is that "I did not solicit it" (Gbadamosi, 2002). The temptation to receive a bribe may arise from many sources, including a pressing financial need for on-going projects, health and other personal or family needs. Alternatively, it may be the pressure of losing one's job if the person does not co-operate with a "clique" that has so perpetuated corruption in the system.

In a survey of 20 African countries the African Bureaucratic Structure Survey (ABSS) found that in many countries it is common for private firms to have to pay some irregular "additional payments" (bribes or tips) to get things done. However, there was a great degree of disparity; ranging from Namibia where bribery was felt to be virtually "non-existent" to Kenya, Nigeria and Togo, where bribery was felt to be "mostly" needed to get things done (Court et al., 1999). The ABSS also investigated the amount tips and bribes have added to basic salaries over the last twenty years in these 20 African countries. The level of bribery seems to have increased for the African sample as a whole and is a serious issue in some countries. Bribery has become endemic in Kenya and Nigeria and is now perceived to almost double bureaucrats' salaries, while it adds very little to salaries in Botswana, Mauritius, Namibia and Tunisia (Court et al., 1999).

Transparency International (TI) has conducted surveys over the last years to establish the perception of corruption around the world, which is popularly referred to as the Corruption Perception Index (CPI). The 2001, 2002, 2003 and 2004 TICPI ranked and listed the corruption perception in 91, 101, 133 and 146 countries. A total of 17 (2001), 20 (2002), 29 (2003) and 36 (2004) African countries were on the list and occupied between rank 26 and 90 (2001), 24 and 101 (2002), 30 and 132 (2003) and between 31 and 144, with most falling over 50 (see Table 1). A CPI score relates to perceptions of the degree of corruption as seen by business people, academics and risk analysts, and ranges between 10 (highly clean) and 0 (highly corrupt). A total of 17 surveys were used from 13 independent institutions, and at least three surveys were required for a country to be included in the CPI. 
Table 1

The Transparency International Corruption Perceptions Index (TICPI) 2001 - 2003 for African countries

\begin{tabular}{|c|c|c|c|c|c|c|c|c|c|c|c|c|c|}
\hline \multicolumn{2}{|c|}{ COUNTRIES } & \multicolumn{3}{|c|}{2001} & \multicolumn{3}{|c|}{2002} & \multicolumn{3}{|c|}{2003} & \multicolumn{3}{|c|}{2004} \\
\hline & & $\begin{array}{l}\text { Africa } \\
\text { rank }\end{array}$ & $\begin{array}{l}\text { World } \\
\text { rank }\end{array}$ & $\begin{array}{l}\text { CPI } \\
\text { score }\end{array}$ & $\begin{array}{c}\text { Africa } \\
\text { rank }\end{array}$ & $\begin{array}{c}\text { World } \\
\text { rank }\end{array}$ & $\begin{array}{l}\text { CPI } \\
\text { score }\end{array}$ & $\begin{array}{c}\text { Africa } \\
\text { rank }\end{array}$ & $\begin{array}{l}\text { World } \\
\text { rank }\end{array}$ & $\begin{array}{l}\text { CPI } \\
\text { score }\end{array}$ & $\begin{array}{l}\text { CPI } \\
\text { rank }\end{array}$ & $\begin{array}{c}\text { World } \\
\text { rank }\end{array}$ & $\begin{array}{l}\text { CPI } \\
\text { score }\end{array}$ \\
\hline 1 & Botswana & 1 & 26 & 6.0 & 1 & 24 & 6.4 & 1 & 30 & 5.7 & 1 & 31 & 6.0 \\
\hline 2 & Namibia & 2 & 30 & 5.4 & 2 & 28 & 5.7 & 3 & 41 & 4.7 & 5 & 54 & 4.1 \\
\hline 3 & Tunisia & 3 & 33 & 5.3 & 3 & 36 & 4.8 & 2 & 39 & 4.9 & 2 & 39 & 5.0 \\
\hline 4 & South Africa & 4 & 39 & 4.8 & 3 & 36 & 4.8 & 4 & 48 & 4.4 & 3 & 44 & 4.6 \\
\hline 5 & Seychelles & - & - & - & - & - & - & - & - & - & 4 & 48 & 4.4 \\
\hline 6 & Mauritius & 5 & 41 & 4.5 & - & - & - & 4 & 48 & 4.4 & 5 & 54 & 4.1 \\
\hline 7 & Egypt & 6 & 54 & 3.6 & 8 & 62 & 3.4 & 6 & 70 & 3.3 & 9 & 77 & 3.2 \\
\hline 8 & Ghana & 7 & 59 & 3.6 & 5 & 50 & 3.9 & 6 & 70 & 3.3 & 7 & 64 & 3.6 \\
\hline 9 & Gabon & - & - & - & - & - & - & - & - & - & 8 & 74 & 3.3 \\
\hline 10 & Benin & - & - & - & - & - & - & - & - & - & 9 & 77 & 3.2 \\
\hline 11 & Morocco & - & - & - & 6 & 52 & 3.7 & 6 & 70 & 3.3 & 9 & 77 & 3.2 \\
\hline 12 & Ethiopia & - & - & - & 7 & 59 & 3.5 & 15 & 92 & 2.5 & 24 & 114 & 2.3 \\
\hline 13 & Malawi & 8 & 61 & 3.2 & 10 & 68 & 2.9 & 11 & 83 & 2.8 & 15 & 90 & 2.8 \\
\hline 14 & Senegal & 9 & 67 & 2.9 & 9 & 66 & 3.1 & 9 & 76 & 3.2 & 14 & 85 & 3.1 \\
\hline 15 & Mali & - & - & - & - & - & - & 10 & 78 & 3.0 & 9 & 77 & 3.2 \\
\hline 16 & Mozambique & - & - & - & - & - & - & 12 & 86 & 2.7 & 15 & 90 & 2.8 \\
\hline 17 & Algeria & - & - & - & - & - & - & 13 & 88 & 2.6 & 19 & 97 & 2.7 \\
\hline 18 & Gambia & - & - & - & - & - & - & 15 & 92 & 2.5 & 15 & 90 & 2.8 \\
\hline 19 & Eritrea & - & - & - & - & - & - & - & - & - & 20 & 102 & 2.6 \\
\hline 20 & Sudan & - & - & - & - & - & - & 19 & 106 & 2.3 & 28 & 122 & 2.2 \\
\hline 21 & Congo, Republic & - & - & - & - & - & - & 21 & 113 & 2.2 & 24 & 114 & 2.3 \\
\hline 22 & Sierra Leone & - & - & - & - & - & - & 21 & 113 & 2.2 & 24 & 114 & 2.3 \\
\hline 23 & Libya & - & - & - & - & - & - & 24 & 118 & 2.1 & 23 & 108 & 2.5 \\
\hline 24 & Zimbabwe & 10 & 68 & 2.9 & 11 & 71 & 2.7 & 19 & 106 & 2.3 & 24 & 114 & 2.3 \\
\hline 25 & Zambia & 11 & 76 & 2.6 & 14 & 77 & 2.6 & 15 & 92 & 2.5 & 20 & 102 & 2.6 \\
\hline 26 & Cote d'Ivoire & 12 & 77 & 2.4 & 11 & 71 & 2.7 & 24 & 118 & 2.1 & 32 & 133 & 2.0 \\
\hline 27 & Tanzania & 13 & 82 & 2.2 & 11 & 71 & 2.7 & 15 & 92 & 2.5 & 15 & 90 & 2.8 \\
\hline 28 & Niger & - & - & - & - & - & - & - & - & - & 28 & 122 & 2.2 \\
\hline 29 & Cameroon & 14 & 86 & 2.0 & 15 & 89 & 2.2 & 27 & 124 & 1.8 & 30 & 129 & 2.1 \\
\hline 30 & Kenya & 15 & 87 & 2.0 & 17 & 96 & 1.9 & 26 & 122 & 1.9 & 30 & 129 & 2.1 \\
\hline 31 & Uganda & 16 & 89 & 1.9 & 16 & 93 & 2.1 & 21 & 113 & 2.2 & 20 & 102 & 2.6 \\
\hline 32 & Angola & - & - & - & 18 & 98 & 1.7 & 27 & 124 & 1.8 & 32 & 133 & 2.0 \\
\hline 33 & $\begin{array}{l}\text { Congo, } \\
\text { Democratic Rep. }\end{array}$ & - & - & - & - & - & - & - & - & - & 32 & 133 & 2.0 \\
\hline 34 & Madagascar & - & - & - & 18 & 98 & 1.7 & 13 & 88 & 2.6 & 13 & 82 & 3.1 \\
\hline 35 & Chad & - & - & - & - & - & - & - & - & - & 35 & 142 & 1.7 \\
\hline 36 & Nigeria & 17 & 90 & 1.0 & 20 & 101 & 1.6 & 29 & 132 & 1.4 & 36 & 144 & 1.6 \\
\hline
\end{tabular}


Much as Table I is largely indicative of corruption perception in Africa, a lot yet remains amiss. Over the last couple of years nearly the same African countries have been recycled in the TICPI surveys, albeit the 2003 and 2004 indices have now added a number of hitherto excluded African countries. It is remarkable that Botswana has consistently remained at the top ranking of the African continent for the last five years and perhaps even more instructive ranking between $24^{\text {th }}$ and $31^{\text {st }}$ in the world makes it a far better performer than some countries in the developed economies and some of the Asian tigers (for example, Botswana ranks higher in the 2004 ranking than Italy, Greece, and Taiwan). Botswana's score places it above 10 members of the European Union included in the survey. Those countries that ranked in the top six in Africa have also recycled themselves within that bracket, making a somewhat consistent performance. Ethiopia has dropped sharply from ranking $7^{\text {th }}$ in 2002 when it first appeared (with a score of 3.5) to $15^{\text {th }}$ in 2003 and $24^{\text {th }}$ in 2004 (with a score of 2.3); while Nigeria has consistently remained at the bottom ranking in Africa in the last 4 years. Specifically focusing on the most current ranking (2004) in Africa, there has been considerable movement on the list compared to the 2003 index. An increase in perceived corruption could be observed for Mauritius and Senegal, while a fall in corruption was perceived in Botswana, Gambia, Tanzania and Uganda according to Transparency International (2005).

Much as the TICPI index remains popular, a number of questions can be asked with respect to its methodology, particularly the sample used in some of the surveys. More significantly, however, are the questions relating to the several cases of the loots of African leaders (former and serving) kept in European and American banks. In many traditional African settings both the thief and his/her collaborators are guilty of inappropriate behaviour. The legal systems in many of the developed countries would concur. Nevertheless, the banking system of the West is rarely condemned for this act of mischievously conniving with the looting leaders while keeping their loots for them without asking questions. Returning the same loot has proven to be problematic, as in the case of Nigeria. The argument that such returned loots could again be misappropriated begs the question and is a red herring.

On the options for combating corruption, the UNDP Discussion papers (1997) noted as follows: "When corruption is endemic, piece meal reforms efforts are unlikely to be worthwhile. Partial solutions can be marginally productive in countries with strong cleangovernment traditions. Other countries need more fundamental reforms because they are caught in a 'corruption trap', in which corruption feeds on itself producing more corruption" (pp. viii).

\section{4}

\section{Corruption perception in Botswana}

The systemic corruption that has plagued most of Africa seems not to have been experienced by Botswana (Charlton, 1990) while that country has again enjoyed relatively good and stable governance since independence in 1966 with having had only three presidents from one political party. Although several corruption scandals in the 1980s involved Botswana's economically and socially important cattle industry (Charlton, 1990), the early 1990s marked a significant turning point for corruption awareness in Botswana. The country was rocked by major corruption scandals among top government functionaries. The revelations came about through the appointment of three Presidential Commissions of Inquiry: two in 1991 and a third one in 1992. The following scenarios may be considered as the opening cases of systematic corruption in Botswana. The first case was the Presidential Commission of Inquiry (1991a), which investigated the circumstances surrounding the supply of textbooks to primary schools for the 1990 school year. The findings of the Commission indicated that formal procedures, especially regarding tender and financial regulations, were not followed. The result was a loss of about P27 million (about US\$15 million then) to government. The second Presidential 
Commission of Inquiry (1991b) dealt with the distribution of land in Mogoditshane (a suburb of the capital Gaborone). The Presidential Commission discovered several cases of abuse in the distribution of land in the area. Some cabinet ministers involved had to resign. The third Presidential Commission of Inquiry (1992) involving another major corruption case, this time a government parastatal - Botswana Housing Corporation (BHC) - that provides housing for the public. In this case the CEO of the parastatal and his deputy were involved in large-scale corruption where they misappropriated the organisation's funds.

The above scenarios were perhaps wake-up calls and seem to have set the stage to re-awaken the anti-corruption drive in Botswana. The government of Botswana has since regarded the issue of ethics and corruption as very important to the long-term strategic objective of the nation, hence the establishment of the Directorate on Corruption and Economic Crime (DCEC). The DCEC was established by act of parliament in 1994 (cited as the Corruption and Economic Crime Act 1994) modelled after the Independent Commission Against Corruption (ICAC) in Hong Kong. Prior to this act, the standards of ethical conduct in the Botswana civil service were based on several government documents that include, but are not limited to, the Public Service Charter; General Orders, and a number of ethics- related guidelines.

The DCEC's objectives include the protection of Botswana from the evils caused by corruption and economic crime. To achieve these objectives, the DCEC adopted a three-prong strategy of combating corruption through: Public Education, Corruption Prevention and Detailed Investigation. One of the most important responsibilities of the DCEC is to promote, among government employees, an understanding of ethical standards for public service (DCEC, 2003). Recently, the DCEC published and launched a booklet on "Ethical Conduct in the Workplace" as another step to ensuring proper ethical conduct in the workplace. It is heart-warming that even though the DCEC was created for the public sector, it has realised the likely futility of its efforts if the private sector is neglected in the drive towards creating a more ethical work culture in the country.

While it is true that most employees are honest, loyal and hardworking and will do what is expected of them, and indeed even exceed this level in certain cases without prompting, there are yet many others who one should not assume possess that strict sense of morality and uprightness required for good ethical conduct in the workplace. This is perhaps why one cannot but agree with the statement of the DCEC Director in his foreword to the booklet cited earlier when he stated "... the hallmark of true service is a willingness to go beyond what is legally required and to act affirmatively to honour trust".

The DCEC is always proud to remind all citizens, residents and visitors to Botswana in conspicuous advertorials that "Botswana has ZERO tolerance for corruption". Another publicised advertisement on billboards and banners indicates "Being HIV Positive is not a Shame, being Corrupt is" to underscore how unacceptable corruption is within the society. These are indications of the need to continue the fight against all forms of corrupt practices to retain the enviable position Botswana currently occupies as it does not take much to damage a good reputation; restoring it when damaged becomes a much more arduous task. The Transparency International Corruption Perception Index (TICPI) has consistently listed Botswana as the least corrupt country in Africa, ranking $26^{\text {th }}$ in the world in 2001 and $24^{\text {th }}$ in 2002 and $30^{\text {th }}$ in 2003 . The key here is that Botswana is committed to inhibiting the development of a culture of corruption. 
Table 2

Statistics of reports received by DCEC since inception

\begin{tabular}{|l|c|c|c|c|c|c|c|c|c|c|c|}
\hline & $\mathbf{1 9 9 4}$ & $\mathbf{1 9 9 5}$ & $\mathbf{1 9 9 6}$ & $\mathbf{1 9 9 7}$ & $\mathbf{1 9 9 8}$ & $\mathbf{1 9 9 9}$ & $\mathbf{2 0 0 0}$ & $\mathbf{2 0 0 1}$ & $\mathbf{2 0 0 2}$ & $\mathbf{2 0 0 3}$ & Total \\
\hline $\begin{array}{l}\text { Number of reports } \\
\text { received }\end{array}$ & 254 & $\begin{array}{c}896 \\
(253 \%)\end{array}$ & $\begin{array}{c}1378 \\
(54 \%)\end{array}$ & $\begin{array}{c}1511 \\
(1 \%)\end{array}$ & $\begin{array}{c}1525 \\
(1 \%)\end{array}$ & $\begin{array}{c}1023 \\
(-33 \%)\end{array}$ & $\begin{array}{c}1475 \\
(44 \%)\end{array}$ & $\begin{array}{c}1841 \\
(25 \%)\end{array}$ & $\begin{array}{c}1779 \\
(-3 \%)\end{array}$ & $\begin{array}{c}1775 \\
(-0.2 \%)\end{array}$ & $\mathbf{1 3 4 5 7}$ \\
\hline $\begin{array}{l}\text { Number where } \\
\text { complainants } \\
\text { identified themselves }\end{array}$ & 237 & $\begin{array}{c}734 \\
(210 \%)\end{array}$ & $\begin{array}{c}1003 \\
(37 \%)\end{array}$ & $\begin{array}{c}1132 \\
(13 \%)\end{array}$ & $\begin{array}{c}1052 \\
(-7 \%)\end{array}$ & $\begin{array}{c}741 \\
(-30 \%)\end{array}$ & $\begin{array}{c}1096 \\
(48 \%)\end{array}$ & $\begin{array}{c}1362 \\
(24 \%)\end{array}$ & $\begin{array}{c}1338 \\
(-2 \%)\end{array}$ & $\begin{array}{c}1419 \\
(6.1 \%)\end{array}$ & $\mathbf{1 0 1 1 4}$ \\
\hline $\begin{array}{l}\text { Number made } \\
\text { anonymously }\end{array}$ & 17 & $\begin{array}{c}162 \\
(853 \%)\end{array}$ & $\begin{array}{c}375 \\
(131 \%)\end{array}$ & $\begin{array}{c}379 \\
(1 \%)\end{array}$ & $\begin{array}{c}473 \\
(25 \%)\end{array}$ & $\begin{array}{c}282 \\
(-40 \%)\end{array}$ & $\begin{array}{c}379 \\
(34 \%)\end{array}$ & $\begin{array}{c}479 \\
(26 \%)\end{array}$ & $\begin{array}{c}441 \\
(-8 \%)\end{array}$ & $\begin{array}{c}356 \\
(-19.3 \%)\end{array}$ & $\mathbf{3 3 4 3}$ \\
\hline $\begin{array}{l}\text { Number of } \\
\text { investigations } \\
\text { commenced }\end{array}$ & 170 & $\begin{array}{c}411 \\
(142 \%)\end{array}$ & $\begin{array}{c}417 \\
(1 \%)\end{array}$ & $\begin{array}{c}316 \\
(-2 \%)\end{array}$ & $\begin{array}{c}31 \% \\
(1 \%)\end{array}$ & $\begin{array}{c}362 \\
(14 \%)\end{array}$ & $\begin{array}{c}390 \\
(8 \%)\end{array}$ & $\begin{array}{c}413 \\
(6 \%)\end{array}$ & $\begin{array}{c}357 \\
(-14 \%)\end{array}$ & $\begin{array}{c}485 \\
(35.9 \%)\end{array}$ & $\mathbf{3 6 3 9}$ \\
\hline $\begin{array}{l}\text { Number of reports } \\
\text { either referred to } \\
\text { other bodies or } \\
\text { retained for } \\
\text { intelligence } \\
\text { purposes }\end{array}$ & 84 & $\begin{array}{c}485 \\
(477 \%)\end{array}$ & $\begin{array}{c}961 \\
(98 \%)\end{array}$ & $\begin{array}{c}1185 \\
(23 \%)\end{array}$ & $\begin{array}{c}1207 \\
(1.9 \%)\end{array}$ & $\begin{array}{c}661 \\
(-45 \%)\end{array}$ & $\begin{array}{c}1085 \\
(64 \%)\end{array}$ & $\begin{array}{c}1428 \\
(32 \%)\end{array}$ & $\begin{array}{l}1404 \\
(-2 \%)\end{array}$ & $\begin{array}{c}1254 \\
(-10.7 \%)\end{array}$ & $\mathbf{9 7 5 4}$ \\
\hline
\end{tabular}

Source: Directorate on Corruption and Economic Crime (DCEC) Annual Report 2003.

The annual percentage change is reported in parenthesis in the table.

The comparative statistics for reports received by the DCEC since inception appear in Table 2. Generally, Table 2 is evidence of the subtle success of the anti-corruption efforts in Botswana. It also indicates a growing number of cases reported and handled by the DCEC since inception, but the annual reports of the body also show a trend that is curious because of the antecedents of the directorate. As noted earlier, events preceding 1994 revealed that a number of top government functionaries were involved in corrupt practices. However, the DCEC reports since 1994 have consistently showed a growing number of petty theft and trivial corruption cases with no "big catches". Frimpong (1997) and Briscoe and Hermans (2000) have also reported this trend. On average, the amount of money involved in most of the completed cases in the last 6 years is about $\mathrm{P} 600.00$, which is about $\$ 150.00$. There are a few isolated cases involving senior public officers (for example, a foreign national working for a public parastatal was prosecuted for trying to influence a tender after collecting a bribe) but none involving a top government functionary or public office holder.
The data published by the DCEC in its annual reports over the last 10 years have indicated that most of the acts of corruption were perpetuated by junior employees, ranging from accounts clerks, vehicle examiners, junior civil servants, to drivers, local businessmen, security guards, receptionists and school teachers. Another interesting fact about the nature of the complaints is that many had to do with allegations of false claims by public officers concerning false claims for subsistence allowance and travelling expenses which were widespread but involved rather small amounts of money. Olowu (1999) cited the Warioba Presidential Commission on Corruption in Tanzania as classifying corruption into two broad forms: petty corruption, associated with poor pay; and large-scale corruption by those determined to make big money. It would appear that the experiences reported in Botswana fall significantly into the former category.

The 1,775 reports received during the year 2003 were classified as follows: 485 cases (27 per cent) were allocated for investigation; 687 cases (39 per cent) were referred to other bodies for further action; in 409 cases ( 23 per cent) advice was given to the person making the 
report; 158 cases ( 9 per cent) were stored in the intelligence database and 36 cases ( 2 per cent) were further reports on matters already reported and classified (DCEC, 2003). The DCEC commenced 485 investigations during 2003, the largest ever commenced within one year, which the agency attributed to the public reporting more relevant cases of corruption and economic crime. However, of all the 1,775 complaints received and within the searchlight of the anticorruption body and thus allocated for investigation in 2003, only 337 (69.6 per cent) were related to corruption, 114 ( 24 per cent) to economic crime, 30 (6 per cent) to money laundering and 4 ( 1 per cent) were to assist other law enforcement agencies (DCEC, 2003). This is, however, an indication that a large number of the complaints received by DCEC are misplaced or inappropriate. A number of the complainants still do not properly discriminate between disciplinary cases, which should be resolved by the organisation, and ethics-related matters needing third-party intervention though investigation as provided for by the law.

The decreasing rate of corruption (at least by public statistics), the impressive ranking of Botswana in the TICPI, and the seeming absence of "big fish" in the catch of the DCEC can be attributed to a number of possible reasons. First, the establishment of the Directorate sounded a warning signal after the scandals of the early 1990s discussed earlier. It is possible that individuals may be shunning corrupt practices or becoming extremely cautious so as not to leave traceable loopholes. Second, the massive education embarked upon by the DCEC may be yielding positive dividends because citizens' awareness is growing with more and better knowledge of the nature and consequences of corruption. For example, the 2001/2002 public awareness surveys indicated a 75 per cent public awareness level, which was an improvement on the earlier survey by about 14 per cent. About 54 per cent of respondents associate the DCEC with bribery issues. In terms of sectoral comparison of corruption proneness, respondents indicated about 49 per cent in the government sector, 17 per cent in the private sector and 15 per cent in parastatals (DCEC,
2002). Third, the corruption prevention drive of the DCEC might also have been a positive factor. The operational procedures of several government departments and activities are assessed annually; such investigations reveal those requiring procedural restructuring and performance improvement. Specific focus is, however, on the removal of opportunities for corruption in the operating system and perceived corruption enhancing work practices. In 2002, for instance, both the Immigration and Labour departments were the focus of such activities since media reports had indicated corrupt practices in the issuance of resident permits, waivers, work permits and similar approvals. A number of revisions in work practices that will reduce or eliminate opportunities for corruption have since been recommended for implementation. Fourth, the print media have also particularly been a champion in the effort to reduce corruption in public offices. They seem to follow any lead they obtain with a lot of publicity, which public functionaries are certainly not always comfortable with. Fifth, the seemingly low involvement of high-ranking public officers and a high proportion of junior officers may be due to the fact that most decisions are made at junior level. For example, the issuance of driver's licences, work permits, residence permit extensions etc. will rarely involve officers at even the middle level of the organisation as such decisions are taken at the lower level. Compared to many other African countries, this particular scenario might be peculiar to Botswana. Finally, the absence of appropriate investigative skills on the part of DCEC officers to detect largescale corruption may also contribute to the seeming absence of "big catches" in the anticorruption efforts.

\section{6}

\section{Anti-corruption efforts in Botswana}

The anti-corruption drive in Botswana is significantly rooted in the efforts of the DCEC. This section discusses some of the problems, limitations and bottlenecks the directorate has to contend with to accomplish its goals and 
objectives. We also identify its unique experiences.

Status of offender: There is the "big fish" versus "small fish" syndrome in the classification of persons being prosecuted for corrupt practices. Perhaps a fish is a fish, irrespective of its size, if the intention of the fisherman is to catch a fish. However, it appears as if only the lower cadre citizens are accosted and tried for corruption offences and not the top civil servants and government functionaries. The status of persons being prosecuted by the DCEC is largely in the former and not the latter category. It could thus be asked, for instance, if some people are untouchable. With the information available on the DCEC and the experiences of its operation since inception, this does not appear to be the case. Without any formal report, media speculations and some measure of facts to trigger off a proper investigation, the DCEC appears incapacitated. It thus remains merely speculation and perception. Yet it is important to remain transparent in its activities because once people start to believe that the absence of a "big catch" by the DCEC is premeditated, much of its public campaign efforts will come to nought. Whenever and wherever this happens or begins to happen, then the fight against corruption is lost. If the experience of several African countries is anything to go by, this scenario may be a major problem in the fight against corruption. If the law is seen as being applied unfairly and unevenly, it soon ceases to be heeded by all.

Trial and prosecution: The 1994 Act establishing the DCEC does not give that body the powers of trial over alleged offenders, rather case files are passed to the Attorney-General's office which is already seemingly overburdened by several other functions with decreasing human resource capacity. As a result, there is a long waiting period to obtain justice because of inadequate personnel and the statutory restriction. Even though conviction rates remain high at 82 percent (DCEC, 2003), the DCEC will perhaps be better off with powers to prosecute its own cases with competent legal practitioners, thus freeing it from the AG's Office.
Public education and rural population: The DCEC's public education drive has been very useful in the anti-corruption efforts of Botswana and it manifests in different forms, including but not limited to brochures, newsletters, promotional materials, posters and banners, magazines and newspapers, press releases, sign posts, public awareness surveys, talks and presentations, radio and television, trade fairs and moral education. Nine years on, surveys have indicated that the public education campaign is yet to reach the heart of Botswana's rural populations (DCEC, 2002). A total of 141 public talks and presentations were conducted in 2003 to a number of different audiences (DCEC, 2003). We may ask, how much of corruption is experienced in the rural setting? Is the rural population a real problem and real threat to the accomplishment of a corrupt-free society? Compared to many other African countries, the opportunities for corruption abound in Botswana's rural areas and this is why the anti-corruption watchdog agency cannot and is not leaving the rural population behind in its anti-corruption efforts. First, public officers in the rural areas have a lot of discretionary powers, which may be abused if proper checks and monitoring are not put in place. Second, public records have shown that corruption is rampant in rural areas, especially in the northern parts of the country where the tourism industry booms. The Community Based Natural Resource Management (CBNRM) opens up interaction between the rural community representatives and safari operators in the area. Monitoring such activities thus becomes important to curb excesses and possible misconduct by both parties.

Corruption prevention efforts: Perhaps the strongest point of the DCEC's efforts, which seems less recognised, is the Corruption Prevention Division - a lot has been done and is still being done by this unit. Some of these activities are reported in the annual reports of the last few years. This is in line with the adage that "prevention is better than cure", which could go a long way in further preventing and possibly ultimately eliminating the ills of corrupt practices. The methods used in 
corruption prevention, especially identifying loopholes in public service performance and blocking such loopholes to minimise the incidence of corruption, offer some lessons to other African countries.

$D C E C$ independence: True, there has been a lot of hue and cry about the limitations of the statute establishing the DCEC because the anticorruption watchdog agency reports to the President of Botswana and its Director is appointed by the President (and by implication may also be fired by the President). To date there has been no indication of abuse. Frimpong (2001) suggested that the DCEC must report directly to Parliament and not to the Presidency, thus freeing it from executive control. A hint of this is also given in the Director's annual report of 2002, tacitly endorsing a World Bank recommendation of 2002. It appears that the proponents of this change are being proactive at the possibility of a future corrupt President appointing its own watchdog.

Encouraging whistleblowing: Encouraging whistleblowing in Botswana may serve a very useful purpose in the fight against corruption. Again, it may serve a positive purpose to initiate some reward for honest public officers or people with exemplary conduct. For example, Table 2 indicates an increase in anonymous reports received by the DCEC from 17 (or about 7 per cent of reports received) in 1994 to 441 (or about 25 per cent of the reports received) in 2002. Whistleblowers are very useful in achieving success in any anti-corruption efforts. Whistleblowing involves going public, often with allegations of wrongdoing or unethical practices (Baron, 1993). The whistleblowers are employees who are willing to risk their careers to alert the public about dangerous or illegal situations. They provide a source of protection to the public by speaking out about such activities. Despite this, whistleblowers are often ostracised from the organisation and treated as outcasts and might even be fired under dubious pretences. Valid acts of whistleblowing employees informing on dubious practices in the workplace - are increasingly being viewed in a favourable light with statutory protection and valid whistleblowing is supported by governments of the USA, UK, Canada, Australia, and New Zealand (Vinten, 2000).

The phenomenon of whistleblowing is, however, relatively uncommon in African society. The African society is based strongly on group bonds and people sticking together at all times. Internal machineries usually exist to correct identified internal problems. As a result, individuals would rarely want to be identified as the odd person out - a deviant of some sort They would not want to be ostracised (Gbadamosi, 2002). Segall (1991) refers to the strong conformity emphasis shown by African societies, the importance of one's own group (or tribe) to the individual and inter-group comparisons in terms of reciprocal group attractiveness and cultural similarity. It may be that individual performance is less important to the African than the spirit of collectivism (Koopman, 1991). However, with the increase in industrialisation, education and improved economic conditions, the phenomenon of whistleblowing may become increasingly popular in the near future in many African countries. South African President Thabo Mbeki, at the Public Sector Anti-Corruption Conference in Cape Town, South Africa in 1998, suggested that the practice of whistleblowing should be institutionalised (Alant \& Uys, 1999). Botswana might benefit significantly by focusing on acts of whistleblowing in the future, perhaps enabling legislation on it and encouraging or even rewarding it.

Recent trend: Finally, the growing trend in corruption and related issues in Botswana seems to be progressing in three main directions. First, the increasing emphasis of the DCEC on offences related to money laundering. In most countries an upsurge of money laundering may be an indication of growing corruption and the need to cover up loots, and thus calls for the kind of attention it seems to be receiving from the DCEC. Second, there is the issue of how to combat corruption in the private sector. This again is an on-going initiative spearheaded by the DCEC in an effort to ensure that the fight against corruption is also private-sector-driven, with the active participation of private sector bodies. Briscoe \& Hermans (2000) noted that 
it is tradition in many countries for businessmen and corporations to take this initiative to reduce the cost of doing business. Third, there is the growing public outcry for the investigation of funding of political parties in the country. With the government currently unwilling and perhaps financially unable to fund political parties, the debate will go on for some time.

Figure 1

A conceptual model of the anti-corruption strategy in Botswana

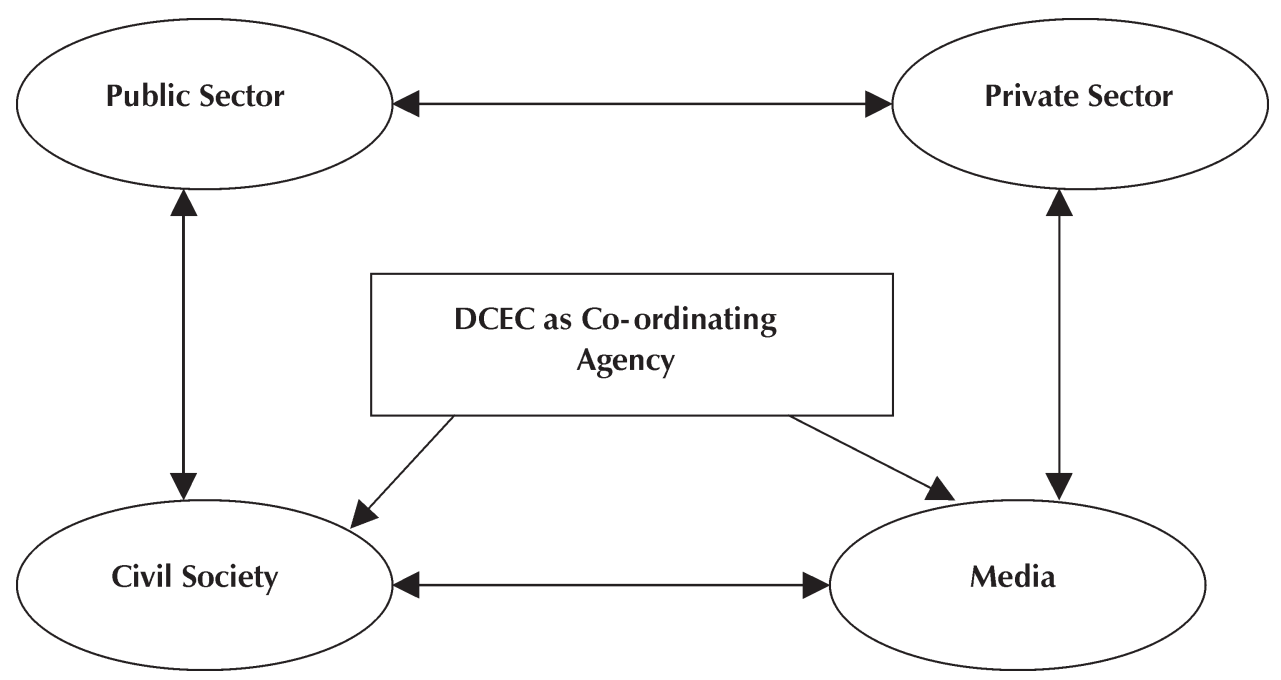

7

\section{Factors aiding anti-corruption efforts in Botswana}

The presence or absence of a number of factors has advanced the fight against corruption in Botswana. They provide opportunities for developing countries and specifically other African countries, particularly those with similar features and characteristics, to study and borrow a leaf or two. It is essential to identify Botswana, though large in physical size, as a small country with some 1.7 million inhabitants, making it structurally different to many other African countries, yet sharing a number of similarities with many others. Some of the relevant peculiarities that might account for its seeming success in the fight against corruption and economic crime are discussed hereafter.

Commitment at the top: Irrespective of the barrage of criticism by Batswana (as citizens of Botswana are known), the commitment of the leadership in ensuring good governance, improving the standards of living of the people and particularly in eradicating corruption, is creditable. This commitment is shown by a good number of leaders in public office, civil service and the parastatals. The importance of top leadership commitment as a critical success factor in an anti-graft strategy is clearly demonstrated in the successes of Hong Kong and Singapore in recent times. In an interview with the director of the DCEC, Frimpong (2001) reported how very clear and committed the DCEC Director is about the agency's mission. A number of media accounts reflect the same view. This commitment comes even from the President, who has been as vocal and as articulate against corruption as he has been about HIV/Aids. Rather than denying allegations raised by the media, the government has generally carried out thorough investigations, but until recently penalties have been small, with key players merely moved around and later returning to their former positions after being re-elected by the majority of the ruling party members (Good, 1994). The same cannot be said of a number of other African 
countries where there has been so much lip service to the fight against corruption.

The place and use of cash: In the last few years Botswana has moved significantly towards becoming a "cashless" society (at least in the cities and towns). In most African countries, with perhaps the exception of a few (e.g. South Africa, Namibia, Egypt, Morocco, Tunisia), economic activities are still significantly cash based, unlike in the developed world, making it difficult to trace how money passes through hands. The use of electronic banking services, credit/debit cards, ATMs, cheques for payments etc. is relatively high in Botswana (at least in the cities and towns) and this reduces the opportunities for corruption significantly because large sums of money not properly accounted for can be traced and questioned. This movement towards a cashless society is vital to minimise corruption and fraudulent practices - it is also a vital lesson for other African economies.

Citizens' registration and identification: The registration of citizens through a detailed and efficient identification process is already taken for granted in Botswana. All Batswana are registered and possess identification cards called Omang. This citizen's registration is not only very useful for crime investigation and minimisation, but also for corruption reduction. Since citizens are easily traceable to their various localities, following up on corrupt practice cases by law enforcement agencies, for example, is likely to yield positive results. In many other African countries there is a very poor record of citizens and hence it is easy for people to remain undetected for a long time.

Education and language: A high level of literacy with people being able to read and write (in any language) facilitates communication and helps to disseminate information. It also advances the course of civic education as well as political and economic participation. Educated citizens are more likely to demand and support accountability and transparency, while others may take little interest in public activities, remaining happy in their own small world. Setswana - the second official language in Botswana - (English being the other) as a medium of communication, is widely spoken and understood throughout the country and hence government can and does aggressively disseminate information to its citizens through this medium. A few other languages are spoken in Botswana, but citizens generally do read and write Setswana. It is thus a significant advantage for the country in its information dissemination and fight against corruption. When this is compared with some other African countries where several hundreds of languages are spoken, for example in Nigeria, where over 250 languages are spoken with a handful being dominant and a much lower literacy rate than Botswana, it is relatively much more difficult for government to disseminate information nationally.

Ethnic and religious issues: Ethnicity and other divides, including a religious divide, can account for all kinds of segregation and seclusion among the people as well as interfere with good sense of judgement of citizens. Many corruption cases have been swept underground on account of this and in the spirit of ethnic bond. This is not such a serious problem in Botswana as it is in many other African countries (e.g. Nigeria). However, recently the drum of such divide has begun to sound louder in Botswana. Apart from the overbearing dominance of the Batswana, there are also other groups like the Kalanga, Basarwa and Kgalagadi and a few others of mainly Asian descent. The problem of ethnicity encourages nepotism and mediocrity - "who you know"; and this also is becoming strong and popular in Botswana.

Civil service reforms: Several recent publicsector reform efforts of government may also be yielding a positive impact. This includes programmes like the Work Improvement Teams (WITS) and the Performance Management Systems (PMS) that are replacing the old Performance Appraisal Systems in the public service. The PMS, for instance, helps to deter corruption because it increases accountability by individual officers. 


\section{7}

\section{Conclusions}

Corruption remains perhaps the biggest threat to the developmental process of any nation. No nation seeking development should allow it to develop into a national habit as it has become in some African countries. When it becomes endemic, as it is reported to be in countries like Kenya, Togo, Cameroon and Nigeria, then it is established, it becomes a habit and people are no longer shocked by it. The disintegration of ethical and moral values worldwide is a phenomenal problem. Globally, there seems to be a desperate ongoing effort to redefine what is right and what is wrong; what is acceptable and what is not; and those values that must change because the world has moved on and we are now in a "global village". The traditional African society was a strict one with well-defined moral standards and conduct. Today, ethics and integrity do not seem important as they no longer have a place in society. With poverty so pervasive in Africa, citizens - especially those who are close relatives and friends to public office holders - now judge public office holders who keep their integrity and remain "poor" in the midst of plenty (public resources) as stupid, naïve and unhelpful.

This paper is a purely descriptive effort, which is a major limitation for any academic effort since descriptive writings lack in-depth rigorous analysis. Moreover, for lack of empirical evidence (since no field study was undertaken), one can only suggest that the Anti-graft agency in Botswana has contributed to the relatively less corrupt environment that is experienced in Botswana compared with many other African countries. Nevertheless, the paper throws open a research agenda as well as challenges for further investigative efforts in at least three interrelated areas. First, the problematic methodology of the TICPI index - for how long would the current method remain acceptable? Second, it would be interesting to know why public perception of corruption in Botswana differs from the facts - and how this, for example, impacts on TICPI results. Third, an analysis of why there has been no focus on the role of Western banks in the pervasive corruption among the elite and successive leadership of African countries.

The negatively and rapidly changing face of corruption, even in Botswana, should however be a cause for concern (Good, 1994; Good; 2002; 2005), albeit a lot more difficult to argue that Botswana is not an example of good practice in the African continent. The arguments going for Botswana include: the relative cultural homogeneity; commitment at the top and competent administration/ leadership over the years; relatively high literacy rate; and political stability, all of which have helped to reduce corruption. Some of these positive landmarks have, however, been taking knocks recently, for example the government handling of the recent deportation of a popular academic from the country, the displacement of the 'Basarwa people' (a minority group in the Botswana) from the central Kgalagadi districts, and the questions about leadership succession in a democratic setting. There is, however, no doubt about the importance of government stability, continuity of successive government programmes through a well thought out succession plan, which arguably should not necessarily be based on Western ideals. One may argue that the practice to date seems to have worked well for Botswana, creating a positive image and reputation worldwide of an open and democratic governance compared with most of Africa.

In summary, this paper has highlighted some of the problems of unethical behaviour in Africa, especially corrupt and fraudulent practices, while demonstrating the importance and effectiveness of an effective fight against corruption as an antidote for economic prosperity. Although we focus on the anti-graft efforts in Botswana, we do not argue that this is responsible for Botswana's relative economic prosperity. Rather, we stress the alarming state of corruption in Africa and hold that the fight against this malaise is rather sluggish, if it is on at all. We especially challenge countries at the lowest ebb of the anti-corruption fight to commence the process belatedly and perhaps borrow useful ideas from Botswana (though a 
relatively small country) where such a fight championed by the government anti-corruption watchdog agency (DCEC) - has been making great strides.

\section{References}

1 ALANT, N. \& UYS, T. (1999) "Whistleblowing: Fighting fraud in organisations", in Rossouw, G.J. \& Carabine, D. (eds.) Fraud and the African Renaissance, Uganda Martyrs University Press: Kampala.

2 BARON, D.P (1993) Business and its Environment, Prentice-Hall, Englewood Cliffs: New Jersey.

3 BBC News: Botswana: Africa's success story? http://newswww.bbc.net.uk /1/hi/world/africa/ 4318777.stm.

4 BRISCOE, A. \& HERMANS, H.C.L. (2000) Combating Corruption in Botswana, Friederich Ebert Foundation: Gaborone.

5 COURT, J.; KRISTEN, P. \& WEDER, B. (1999) "Bureaucratic structure and performance: First African survey results", Work in Progress. http:// www.unu.edu/hq/academic/Pg_area4/bstructure.html.

6 CHARLTON, R. (1990) "Exploring the byways of African political corruption: Botswana and deviant case analysis", Corruption and Reform, 5(1): 1-27.

7 DIRECTORATE ON CORRUPTION AND ECONOMIC CRIME, 1999 Annual Reports, Government Printers: Gaborone.

8 DIRECTORATE ON CORRUPTION AND ECONOMIC CRIME, 2000 Annual Reports, Government Printers: Gaborone.

9 DIRECTORATE ON CORRUPTION AND ECONOMIC CRIME, 2001 Annual Reports, Government Printers: Gaborone.

10 DIRECTORATE ON CORRUPTION AND ECONOMIC CRIME, 2002 Annual Reports, Government Printers: Gaborone.

11 DIRECTORATE ON CORRUPTION AND ECONOMIC CRIME, 2003 Annual Reports, Government Printers: Gaborone.

12 FRIMPONG, K. (1997) "An analysis of corruption in Botswana", paper presented at a Workshop on Corruption and Integrity Initiatives in the Context of Developing Economies, held in Paris, 24-25 October 1997.

13 FRIMPONG, K. (2001) National Integrity Systems Country Study Reports (Unpublished commissioned report, Gaborone, Botswana).
14 GBADAMOSI, G. (2002) "Managerial challenges of ethical business practices in Africa", in Kaynak, E. \& Sarvan, F.D. (eds.) The Impact of Globalization on World Business in a New Millennium: Competition, Cooperation, Environment, and Development, Proceedings of the Eleventh World Business Congress, (IMDA), Antalya, Turkey: 118-125.

15 GIBSON, K. (2000) "Excuses: Moral slippage in the workplace", Business Horizon, 43(6): 65-70.

16 GIRLING, J. (1997) Corruption, Capitalism and Democracy, Routledge, London and New York.

17 GOOD, K. (1994) "Corruption and mismanagement in Botswana: A best-case example", Journal of Modern African Studies, 32(3): 311-327.

18 GOOD, K. (2002) "Rethinking nonaccountability and corruption in Botswana", Africa Insight, 32(3): 11-18.

19 GOOD, K. (2005) "Resource dependency and its consequences: The costs of Botswana's shining gems", Journal of Contemporary African Studies, 23(1): 27-50.

20 HOPE, K.R. (2002) "From crisis to renewal: development policy and management in Africa", Koninklijke, Leiden. African Social Studies Series, 5.

21 KOOPMAN, A. (1991) Transcultural Management: How to Unlock Global Resources, Blackwell: Oxford.

22 OLIVER DE SARDAN, J.P. (1999) "A moral economy of corruption in Africa", Journal of Modern African Studies, 37(1): 25-52.

23 OLOWU, B. (1999) "Combating corruption and economic crime in Africa: an evaluation of the Botswana Directorate of corruption and economic crime", The International Journal of Public Sector Management, 12(7): 604-614.

24 REPUBLIC OF BOTSWANA (2001) "Economic snapshot", http://www.gov.bw/ economy/index.html.

25 SEGALL, M.H. (1991) Cross-cultural Psychology: Human Behaviour in Global Perspective, Wadsworth: Belmont, CA.

26 STAPENHURST, R. \& KPUNDEH, S.J. (eds.) (1999) "Curbing corruption: Towards a model for building national integrity", EDI Development Studies, The World Bank: Washington, D.C.

27 STAPENHURST, R. \& SHAHRZAD, S. (1999) "Introduction: An overview of the costs of corruption and strategies to deal with it" in Stapenhurst, R \& Kpundeh, S.J. (eds.) (1999) Curbing Corruption: Towards a Model for 
Building National Integrity, EDI Development Studies, The World Bank, Washington, D.C. 1-9. 28 THE REPORT OF THE PRESIDENTIAL COMMISSION OF INQUIRY INTO IPM CONSULTANCY (1991a) Government Printers: Gaborone.

29 THE REPORT OF THE PRESIDENTIAL COMMISSION OF INQUIRY INTO LAND PROBLEMS IN MOGODITSHANE AND OTHER PERI-URBAN VILLAGES (1991b) Government Printers: Gaborone.
30 THE REPORT OF THE PRESIDENTIAL COMMISSION OF INQUIRY INTO THE BOTSWANA HOUSING CORPORATION (1992) Government Printers: Gaborone.

31 UNDP (1997) Corruption and Good Governance: Discussion paper 3, Management Development and Governance Division, UNDP, New York.

32 VINTEN, G. (2000) "Whistleblowing towards quality", The TQM Magazine, 12(3):166-171.

33 WORLD BANK (1997) "The state in a changing world" World Development Report, Washington DC: Oxford University Press. 